\title{
Eleatic Ontology: origin and reception
}

\section{Introductions}

\author{
Rose Cherubin \\ Associate professor of philosophy at George Mason University \\ https:/orcid.org/0000-0002-1709-7510 \\ rcheruhi $(a)$ gmued \\ Nicola Galgano \\ Researcher at Universidade de São Paulo \\ https://orcid.org/0000-0002-6876-1119 \\ nicola galgano@hotmail.com \\ Massimo Pulpito \\ Researcher at Archai - Universidade de Brasília \\ https:/orcid.org/0000-0002-1488-747X \\ multiplo@gmail.con \\ Fernando Santoro \\ Associate Professor at Universidade Federal do Rio de Janeiro \\ http://orcid.org/0000-0001-6923-053 \\ fsantoro68@gmailicon \\ Recebido: 30 de setembro de 2020 \\ Aprovado: 30 do setembro de 2020 \\ DOI: https://doi.org/10.47661/afcl.v14i27.40619
}




\section{General Introduction}

The central idea of Eleatic Ontology: origin and reception is to gather in one editorial product a description of Eleatic ontology, its first developments, and its lasting and powerful influence on all western thought.

In the past, works of large dimension, such as that proposed here, required the coordination of many intertwined components and the solution of many difficulties, beginning with economic ones. For these reasons, they were rare and came about only for topics that were held to be important enough to justify substantial engagement and investments. Today, telecommunications and electronic publishing, together with more dynamic organization and interaction within the international academic community, enable one to overcome many of these problems.

This kind of large work may bring to mind ideas such as 'encyclopedia', 'handbook', 'history of...', and many other genres of writing that intend to be exhaustive on a given topic. That would not be wrong; but we should pay due attention to current conditions and new social requirements. If cultural closures and social rigidity were the old problems - mainly through the lack of certain technologies - the current cultural and social fluidity in exchanging information have reached a degree sufficient to generate and justify even such notions as 'liquid society'. The reason is simple: all knowledge is easily available (or, at least, more easily than before). From this, the data crossing in so many and such diverse minds generates new insights, concepts and ideas, which result immediately in new deliveries in the cultural common inheritance. Take for example Wikipedia: the old idea of enclosing all knowledge in one work (the encyclopedia) is confronted with the new idea of 'opening' the knowledge to everyone. New knowledge is immediately generated and Wikipedia is constantly 
updated in the exact measure in which exhaustiveness allows a qualitative and quantitative overcoming of itself, with new ideas as the result of a new gestalt of earlier ones.

Considering the new social and cultural conditions, the ambition of this enterprise is the composition of a complete work, which would be perfectible in the sense made possible in our current world by the new cultural and technological dynamics: it would be an intervention in multiple streams of a cultural vortex, furthering research and inclusive dialogue without claiming to be a final statement.

The method we have devised in order to attend to the conditions mentioned above consists mainly in the simultaneous cooperation of a large team. By relying on electronic communication and publishing, we believe that is possible to scaffold devices of production, selection and publication that can work across a wide range of sources, geographical locations, and technologies in a short time.

Some parts of this large project are easier to accomplish than others. For this reason, whereas the editorial plan reflects the chronology of historical development, the timeline is organized according to the time projected for the completion of each volume, starting with the one that will likely take the least time, and finishing with the one that is projected to take the longest time and most complex efforts.

The work is divided into 4 major periods composing 4 Volumes:

1) Eleatic ontology in ancient philosophy;

2) Eleatic ontology in medieval philosophy;

3) Eleatic ontology in modern philosophy;

4) Eleatic ontology in contemporary philosophy.

Each Volume is a collection of Tomes, and each Tome is composed of articles from authors devoted to its specific topic. Twothirds of the essays were invited contributions from the most renowned scholars in their respective fields, while the other third was selected by 
blind review from submissions by young and mid-career researchers. This fosters the development of new scholarship in dialogue with more established work, and opens both to new and broader audiences.

For now, Eleatic Ontology: origin and reception is a work in progress. We hope to accomplish it in reasonable time.

General Editor

Nicola S. Galgano 


\section{Introduction to Volume 1}

The title of the research project that inspires the series of contributions collected here hides a lexical and historiographical problem: what is 'Eleatic ontology'? The word 'ontology' is certainly modern, dating back (as far as we know today) to the early seventeenth century. Furthermore, the first to speak of an 'Eleatic race' was Plato about a century after the existence of this alleged school, in the Sophist (242d), with reference to Elea, the city where Xenophanes apparently had arrived and where Parmenides and Zeno were born and lived. On both components of the phrase there were debates aimed at clarifying, on the one hand, what ontology was, if it had a different status from that possessed by metaphysics (in the first attestation known to us, in Jacob Lorhard's Ogdoas Scholastica in 1606, metaphysics and ontology were used synonymously); on the other hand, whether it is pertinent to speak of an Eleatic school that groups after all very different thinkers. Nevertheless, Parmenides indeed was the first to conduct an articulated reflection on to on (eon in the Ionian dialect), calling the discourse on this entity logos. Therefore, 'ontology', although of modern coinage, does not seem to be a completely inadequate term. As for Eleaticism, while it is true that speaking of a school with real discipleship or at least of a current characterized by philosophical continuity is highly questionable, there is no doubt that the most representative and innovative exponents of this heterogeneous group were the two thinkers of Elea. And this just as we cannot deny (despite the diversity, if not even the controversy) precise lines of influence that bind the Eleatics to thinkers from different areas (starting from Melissus of Samos).

The first volume of the project Eleatic Ontology: Origin and Reception focuses its gaze on ancient philosophy, where the main characteristics of a prospective Eleatic ontology have been forged. In 
ancient Greek thought, we find the origin of this theoretical perspective, in the work of Parmenides and the other Eleatics (in fact, Zeno, and, honoris causa, Melissus the Samian), who in their own way testify to a first reception of Parmenideanism. Thereafter, ancient philosophy has repeatedly shown examples of reception of this standpoint, and it was this Nachleben that was, in turn, the origin of the notion (or cliché) of Eleatic ontology in the following centuries.

A first Eleatic tenet concerned the question of language as a conventional expression of being and truth, a theme object of reflection among the Sophists (and of which we also find traces in the Platonic Cratylus), as well as the use of the paradox that we find in a Socratic school of probable Eleatic ancestry, the Megaric. But the image of Eleaticism that has been formed over time revolves mainly (although not exclusively) around two thematic nuclei: monism and immobility. The issues of the uniqueness and the stillness of the whole Being were at the center of debates that have brought the questioning of plurality and movement back to Eleaticism. Overcoming these (sometimes simplified) theses influenced the development of following thought. In classical philosophy, Parmenides is paired, on the one hand, with Zeno for the negation of plurality and movement, and on the other, with Melissus for the thesis of the uniqueness and immobility of the whole. With Hellenistic philosophy, in addition to the theme of the critique of the senses, which has given rise to a sceptical reading of Eleaticism, we find attributed to Eleaticism a particularly strict form of monism which (although probably first conceived by Melissus) begins to be retroprojected to Parmenides. Precisely on the nature of this alleged monistic ontology, a debate opened that would also involve the Neoplatonic philosophers, who instead recognized in the doctrine of the thinkers of Elea a proto-platonic dualism, derived from the recognition of an intelligible plane separate from the sensible one, and therefore not identifiable with a strict monism.

This first Volume collects essays addressing the multiple features 
of this complex history, investigating, in an often innovative way, aspects that are sometimes overlooked or in any case not examined with due attention.

It is subdivided into six Tomes:

1.1) Eleatic ontology in Parmenides, Zeno and Melissus;

1.2) Eleatic ontology in the Sophists and Pluralists;

1.3) Eleatic ontology in Socrates and Socratic schools;

1.4) Eleatic ontology in Plato;

1.5) Eleatic ontology in Aristotle;

1.6) Eleatic ontology in Hellenistic period to Late Antiquity.

Each of these sections studies, in chronological order, a crucial moment in the history of Eleatic ontology, its transformations and survivals, demonstrating that philosophy has had to deal for a very long time with the shadow of 'Parmenides the Great' (Sph. 237a) and his epigones.

Massimo Pulpito 


\section{Introduction to Tome 1.1}

The word 'ontology' had its debut in 1606, in the title of a book by Jacob Lorhard, as recently discovered by Raul Corazzon. ${ }^{1}$ From there on it met an outstanding success and was used to indicate a discipline or a body of knowledge, with a number of meanings that range from Lorhard's first definition 'philosophia de ente' to the most recent meanings related to information science. Between these two points in time, i.e. across 400 years, 'ontology' was understood in many ways; and, most important for us, it was used retrospectively.

Interpreting ancient thought with anachronistic conceptual frames is a very dangerous operation in historiography of philosophy and there are many examples of failed attempts (e.g. references to materialism before Aristotle or to a unique transcendent god before, say, Augustine). However, there are concepts that resisted the anachronism and seem to be very appropriate for translating the ancient ways of thinking. A classical example is the term 'metaphysics' when applied to Aristotle as a title and content of one of his most important works. Aristotle never used this word, nor even this notion. However, a notion related to a body of knowledge concerning what is beyond the physical world came to be very appropriate for the highest themes that he studied in those texts. In fact, the origin of the term refers to a pool of manuscripts that the editor (possibly Andronicus of Rhodes, $1^{\text {st }}$ century $\mathrm{CE}$ ) put after (meta) the books of physics.

Some scholars think that it is mistaken to consider the word 'metaphysics' to refer to a "study that somehow "goes beyond" physics, a study devoted to matters that transcend the mundane concerns of

${ }^{1}$ R. Corazzon, "Birth of a New Science: The History of Ontology from Suárez to Kant ", Ontology, https:// www.ontology.co/history.htm . 
Newton and Einstein and Heisenberg." 2 We can agree with these scholars' understanding. However, in the case of Aristotle's Metaphysics, it is a fact that it studies matters that do not concern physics, i.e. do not concern beings in movement, following Aristotle's own description. ${ }^{3}$ Still, the ambiguity between "after the Physics" and "beyond the physics" remains, because, on the other side, Aristotle himself did not define the matter in a unique way. In Book A he says that sophia "is concerned with the primary causes and principles" (A1 981b28) and then "Wisdom is knowledge of certain principles and causes" (A1 982a2). In Book $\Gamma$ we find that this knowledge is about "a science which studies Being qua Being, and the properties inherent in it in virtue of its own nature." ( $\Gamma 1$ 1003a21-22) and this same formula can be found in Books E and K. In Book E, we also find this science described as "theology" (E1, 1026a19) and "primary philosophy" (E1, 1026a24).

This multiple description regarding one and same science took the successful name of 'metaphysics' and held its ambiguity ${ }^{4}$ until the period we considered above, i.e. the sixteenth-seventeenth century. It was then that, on one hand, some matters traditionally belonging to physics (e.g. the relation of mind and body, or the freedom of the will, or

2 van Inwagen, Peter and Meghan Sullivan, "Metaphysics", The Stanford Encyclopedia of Philosophy (Spring 2020 Edition), Edward N. Zalta (ed.), URL = https://plato.stanford.edu/archives/spr2020/entries/metaphysics/ >.

${ }^{3}$ Phys. 185a 13-4: "Let us then start from the datum that things of Nature, or (to put it at the lowest) some of them,

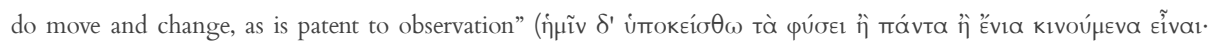

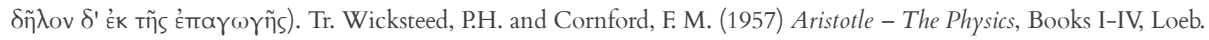

${ }^{4}$ Cf. Clemens Timpler, Metaphysicae systema methodicum, Steinfurt, Caesar, 1604, p. 3 : "Dicitur Metaphysica a Scholasticis, vel quasi Postphysica, quod post rerum naturalium cognitionem demum a Philosophis fuerit inventa: vel quasi Transphysica, quod ea tractet, quae fines et limites Physicae transcendant, et supra res naturales ordine naturae seu dignitatis sint collocata." (cited in Ragni,A. and Carraud, V. (2020) Le neologisme orgueilleux. Les Études philosophiques, 203, p. 3-15. Available online: https://www.cairn.info/revue-les-etudes-philosophiques-2020-3page-3.htm 
personal identity across time), were assigned to metaphysics ${ }^{5}$ and, on the other, the necessity arose of defining a science that could escape the ambit of Theology. Already in Pereyra (De communibus omnium rerum naturalium principiis et affectionibus, Roma 1576) we find a first division between prima philosophia and metaphysica. Some years later, Lorhard published the first edition of Ogdoas scholastica, which had in its frontispiece the term ontologia. From there on, the term and the notion it carried passed from a professor to another until the publication of Wolff's Philosophia prima sive Ontologia, which finally and definitely spread them among scholars.

Most of the many definitions of ontology center upon "the science of being," better specified by "the science or study of being as such". Without entering into deep discussions about these definitions, what is really important for us is the fact that a study of being is historically found for the first time in Parmenides of Elea. There are no other testimonies that can direct us to possibly lost authors; all tradition refers to Parmenides as the unique philosopher who discussed being for the first time. And thanks to Simplicius (in Ph. 144.25, DK28A21), we retain what presumably is the first complete discussion on to eon, being, numbered as B8 by Diels, in Parmenides' poem. In addition, before B8 there are many statements about what-is and what-is-not; it is very much worth noting that the poem presents a short but very important argument about to mē eon, non-being, in B2, before any other discussion on being. This fact may suggest that Parmenides had a deep acknowledgment of the complexity of this matter. Hence, it is not without reason that Hegel, amazed by the notion of Being and its dialectical process, assigned to Parmenides the beginning of the real -

\footnotetext{
${ }^{5}$ Cf. the description of Jean-François Courtine: “Pérérius faisait signe vers ce qui n'apparaissait encore qu'en creux, comme une science autre que la théologie, et qu'il fallait élaborer dans sa spécificité propre. La rupture brutale qu'instituait ainsi Pererius au sein de l'édifice traditionnel de la Métaphysique, allait permettre de libérer une nouvelle démarche qui ne serait plus secrètement orientée vers la scientia divina ; celle-là même qui était destinée à recevoir bientôt après le nom d'ontologia." Courtine, J.-F. 1990, Suarez et le système de la métaphysique. Paris, PUF.
} 
from his point of view - philosophy. ${ }^{6}$

Nowadays, images of Parmenides can be found at the entry ontology in Wikipedia pages in many languages, including the English and the Japanese ones. With him, in this same philosophical topos, we find what is termed Eleatic thought, which is linked mainly to Zeno and Melissus. Hence, the Eleatikon ethnos (Sph. 242 d4), which could have been just a fiction of Plato's, still stands as a referential pillar in the history of philosophy. In addition to Parmenides' fame as the father of ontology, there are new developments in scholarly research that are sharpening and sometimes even challenging that traditional image. The cause of this continuous liveliness in Parmenidean studies may be found in two very different elements that, in this case, work synergistically. On one hand, the poem came to us very incomplete. On the other, the Parmenidean style in association with a very exceptional philosophical depth work together in originating many different and sometimes opposite interpretations. In fact, even with respect to Parmenidean ontological matters, the literature produced and produces many approaches that result in many different views: logical, metaphorical, mythical, anthropological, scientific and more. For these reasons, first of all it is impossible to come to a unanimous interpretation; and second it is exactly these multiple views that make the anti-intuitive Eleatic ontology so rich and so alive after two and half millennia.

The liveliness of the contemporaneous scholarly studies can be seen in the pages of this Tome 1 of Volume 1 of Eleatic ontology: origin and reception. The reader will find 15 articles of some of the most

\footnotetext{
6 These are his words: "Since in this an advance into the region of the ideal is observable, Parmenides began Philosophy proper. A man now constitutes himself free from all ideas and opinions, denies their truth, and says necessity alone, Being, is the truth." (Mit Parmenides hat das eigentliche Philosophieren angefangen; die Erhebung in das Reich des Ideellen ist hierin zu sehen. Ein Mensch macht sich frei von allen Vorstellungen und Meinungen, spricht ihnen alle Wahrheit ab und sagt: Nur die Notwendigkeit, das Sein ist das Wahre.) (Hegel, G. (1833) Vorlesungen über die Geschichte der Philosophie, I. In Werke, 18, p. 291, auf der Grundlage der Werke von 1832-1845 neu edierte Ausgabe, Redaktion E. Moldenhauer und K.M. Michel, Suhrkamp, Frankfurt am Main 1986 e ss. Eng. Trans. (1892) Lectures on the history of philosophy. Kegan, Trench, Trübner, London.
} 
important scholars of Eleaticism, including both some of the most famous and some who are less famous but whose work deserves attention. Their different approaches, points of views, and interpretations should be seen as the result of the unlimited fertility of the Eleatic sophoi's immortal pages. Few philosophers in the history shake our minds as much as Parmenides, Zeno and Melissus; almost surely even fewer shake us more than they do. The philosophical impact of reflections on an unmovable, ungenerated, one, infinite being with the annexed necessity of thinking about movement, generation, oneness and multiplicity, infinity etc. was and is so great that no one could exhaust their philosophy for centuries. A similar picture can be found here by the reader:

- historical problems, as the relation between Parmenides and Heraclitus (Berruecos) or the misguiding reception of the poem in Plato and Aristotle (Cordero) or the new portrait of Zeno (Rossetti);

- religion, the relation between the gods of the poem and what-is (Bryan);

- epistemology and gnoseology, the relevance of Parmenides' ontology (Calenda) or the problem of knowing what-is and what-is-not (Lesher);

- ontological problems, such as Eleatics' contribution to ontology (Cherubin) or the ontology of DK28B4 (Fratticci) or ontological characters of being (Mogyorodi);

- the relation between doxa and ontology, as in Conte, or the metaphysics of Doxa (Graham) or again ontology and doxa (Thanassas);

- meontology in Parmenides (Galgano) or in Melissus (Pulpito);

- dulcis in fundo, Parmenides' cosmic Eros (Santoro).

All these articles will give in detail the most recent outcomes in 
the advanced Eleatic research. We think that the whole Tome traces a meaningful prospect of Eleatic scholarship in this first quarter of our century, a solid step from which any interested reader can move forward in his or her own area of interest.

The Editors of Volume 1 Tome 1

Nicola Galgano

Rose Cherubin 


\section{The Editorial Project}

Project EON- Eleatic Ontology: origin and reception (also called EON Project) is a broad international and cooperative work. The publication of its results is initially hosted by the on-line journal Anais de Filosofia Clássica [Proceedings of Classical Philosophy] edited by the Philosophy Graduate Program of Federal University of Rio de Janeiro. The first Tome of Volume 1 is here published in issues 27 and 28, making up a special dossier in $A F C$ Volume 14. Subsequently, we will publish this Tome also in electronic and printed book formats, with internal indexes. Other volumes of the EON Project may also be published initially in other specialized journals.

The choice to start with the Brazilian journal Anais de Filosofia Clássica is not merely casual. The journal, which reaches 14 years of regular publications with a complete layout renewal in 2020, was inaugurated with a volume entirely dedicated to Parmenides in 2007, right after an international symposium dedicated to the philosopher, held in the city of Rio de Janeiro. Since then, many of the collaborators of the EON Project have written articles in Anais de Filosofia Clássica, so we were glad that they felt at ease when they heard that this journal would be the first host of the essays for Project EON.

Embracing the EON Project in the $A F C$ journal brought a new element to the international collaborative vocation of this undertaking, though. $A F C$ is not only a multilingual periodical, but it also promotes multilingualism and translation as a way of sharing and diversification of thought experiences, ever made in languages. To publish a volume as a book is still an editorial project to be accomplished in English, today's lingua franca. The publication of articles in digital media, however, has made it possible to add the original languages in which some texts were written. Thus, sometimes we will have bilingual versions of the articles for Project EON. In the first issue, for example, we present the English and French versions of Néstor-Luis Cordero's paper. Here, Eleaticism 
joins multiplicity.

Fernando Santoro

Editor in charge of Anais de Filosofia Clássica

\section{Collaborators for this Tome}

The editors

Editor of Anais de Filosofia Clássica: Fernando Santoro

Editors of Volume 1 Tome 1: Nicola S. Galgano and Rose Cherubin

Advising Editor: Massimo Pulpito

Editorial assistants: Samuel Martin, John McMullen

The authors

Bernardo Berruecos Frank is a researcher and professor of Greek and Greek Literature and Philosophy at the Institute of Philological Research of the National Autonomous University of Mexico (UNAM). He specializes in Greek epic and lyric poetry and presocratic philosophy, particularly in Parmenides' Poem.

Jenny Bryan is Senior Lecturer in Classical Philosophy at the University of Manchester, UK. She has published on early Greek philosophy, Plato, and Hellenistic philosophy.

Guido Calenda is a former engineering professor at the University of Roma Tre, retired, and is the author of books and articles on presocratic philosophy.

Rose Cherubin is associate professor of philosophy at George Mason University. She has written on the Eleatics, Aristotle, and early Greek poetry, an on justice and truth in early Greek thought.

Bruno Conte is professor of History of Philosophy at the Pontifical 
Catholic University of São Paulo (PUC-SP) and post-doctoral researcher at the University of São Paulo (USP). His main interests are in the presocratics, Plato and Aristotle.

Nestor-Luis Cordero is two times Doctor of the Universite de Paris IV (Sorbonne). He is a specialist in presocratic philosophy, especially in Parmenides' thought. He was declared First Honorary Citizen of Elea.

Walter Frattici is professor of philosophy at Istituto Teologico Leoniano of Anagni. He has written mainly on Parmenides and the theme of the truth.

N. S. Galgano is a researcher at Universidade of São Paulo, with a production of books and articles mainly on Eleaticism and the theme of non-being in Antiquity.

Daniel W. Graham is emeritus professor of philosophy at Brigham Young University. He has written extensively on Presocratic philosophy, Socrates, Plato, Aristotle, and early history of science.

James Lesher teaches philosophy at the University of North Carolina at Chapel Hill and is the author of four books (including Xenophanes of Colophon, Toronto, 1992) and more than 70 articles on aspects of ancient Greek thought.

Emese Mogyoródi is associate professor of philosophy at the Department of Philosophy, University of Szeged, Hungary. She has written on Greek literature (Homer, Sophocles), the Presocratics (especially on Xenophanes, Heraclitus and Parmenides), the historical Socrates, the historical Gorgias, and Plato's ethics and political philosophy.

Massimo Pulpito has a $\mathrm{PhD}$ in History of Philosophy from the University of Macerata and the University of Siena. He has written mainly on Parmenides, Melissus and Zeno.

Livio Rossetti has been professore di Storia della Filosofia Antica in the Università di Perugia, Italia. His areas of investigation include the Presocratics, the Socratics (Plato included), and Greek Law. 
Panagiotis Thanassas is Associate Professor of Philosophy at the University of Athens. His research, mostly inspired by philosophical hermeneutics, focuses on Parmenides, Plato, Hegel and Heidegger.

Fernando Santoro is Associate Professor of Philosophy at the Federal University of Rio de Janeiro, he has written on early Greek poetry and philosophy (especially on Sapho, Xenophanes, Empedocles and Parmenides) and ancient poetics.

\section{Acknowledgments}

We would like to thank the many institutions and their people that collaborated with Eleatic Ontology: origin and reception. Vol. 1, Tome 1 :

Universidade de São Paulo, FFLCH, Departamento de Filosofia: Prof. Dr. Roberto Bolzani Filho; Secr.: Marie Marcia Pedroso and Luciana Nobrega.

George Mason University, Department of Philosophy: Prof. Rachel Jones; Mr. Kenneth Santos; Mr. Samuel Martin; Mr. John McMullen

Universidade Federal do Rio de Janeiro, Laboratório OUSIA do Programa de Pós Graduação em Filosofia: Prof. Dr. Beatriz de Paoli; Prof. Dr. Tatiana Ribeiro; Dr. Luiz Otávio de Figueiredo Mantovanelli; Mr. Luan Reboredo; Dr. Lúcio Lauro Salles; Prof. Dr. Cristiane Azevedo; Dr. Constança Barahona; Dr. Verônica de Araújo Costa.

Universidade Federal do Rio de Janeiro: Projeto Capes/Print Dicionário dos Intraduzíveis, Programa de Pós-Graduação em Filosofia: Prof. Dr. Henrique Cairus.

Universidade de Brasília: Prof. Dr. Gabriele Cornelli.

Universidade Federal do Espírito Santo: Prof. Dr. Thana Mara de Souza, Prof. Dr. José Renato Salatiel. 
References

CORAZZON, R. " Birth of a New

Science: The History of Ontology from Suárez to Kant ", Ontology, URL

$=<$ https://Www.ontology.co/ history.htm $>$.

COURTINE, J.-F. (1990), Suarez et le système de la métaphysique. Paris, PUF.

HEGEL, G. (1833) Vorlesungen über die Geschichte der Philosophie, I. In Werke, 18, p. 291, auf der Grundlage der Werke von 1832-1845 neu edierte Ausgabe, Redaktion E. Moldenhauer und K.M. Michel, Suhrkamp, Frankfurt am Main 1986 e ss. Eng. Trans. (1892) Lectures on the history of philosophy. Kegan, Trench, Trübner,
London.

van INWAGEN, P. and MEGHAN S. (2020) "Metaphysics", The Stanford Encyclopedia of Philosophy (Spring 2020 edition), Edward N. Zalta (ed.) URL = $<$ https://plato.stanford.edu/archives/ spr2020/entries/metaphysics/>.

RAGNI, A. and CARRAUD, V. (2020) Le neologisme orgueilleux. Les Études philosophiques 203, p. 3-15. URL = <https://www.cairn.info/revue-lesetudes-philosophiques-2020-3page-3.htm >.

WICKSTEED, P.H. and CORNFORD, F. M. (1957) Aristotle - The Physics, Books I-IV, Loeb.

This study was financed in part by Coordenação de Aperfeiçoamento de Pessoal de Nível Superior - Brasil (Capes) - Finance Code 001

O presente trabalho foi realizado com apoio da Coordenação de Aperfeiçoamento de Pessoal de Nível Superior - Brasil (Capes) - Código de financiamento 01 